УДК 8 г.25

ББК $83+8 \mathrm{I} \cdot 2-7$
ДИСКУССИЯ О ТИПАХ

ХУДОЖЕСТВЕННОГО ПЕРЕВОДА

В СОВЕТСКОМ ПЕРЕВОДОВЕДЕНИИ

(C) 2017 г. Н.Р. Нейман

Холонский Технологический Институт,

Холон, Израиль

Дата поступления статьи: 27 марта 2017 г.

Дата публикации: 25 июня 2017 г.

DOI: IO.22455/2500-4247-20I7-2-2-I90-2II

Аннотация: Статья посвящена теории и истории художественного перевода в Советском Союзе, а именно взаимоотношениям московской и петербургской школ перевода. В статье обсуждается глава из незаконченной докторской диссертации кандидата филологических наук, переводчика и теоретика перевода В.Е. Шора (I9I7-I97I) «Сколько существует типов художественного перевода?», которая была отвергнута редакторами ведущих сборников в этой области. В.Е. Шор выступил против идей, поддерживающихся школой И.А. Кашкина, хотя и критиковал в основном идеи Б.Б. Вахтина, который не принадлежал к московской школе перевода. Шор считал невозможным деление переводов на различные типы, поскольку оригинал должен был определять тип перевода, и выдвинул единый универсальный принцип определения критериев качества перевода, который научно обосновывает необходимость творческих поисков переводчика и в то же время имеет целью как можно полнее воплотить идеи и образы оригинала на языке перевода. В статье показано, как ожесточенная борьба между сторонниками двух школ перевода повлияла на отказ в публикации статьи, которая представляла идеи, не соответствующие генеральным направлениям в переводоведении г96о-х гг.

Ключевые слова: художественный перевод, теория и история перевода в СССР, типы переводов, адекватность перевода, буквализм и вольничанье, Петербургская школа перевода.

Информация об авторе: Наталия Романовна Нейман - кандидат филологических наук, преподаватель кафедры английского языка Холонского Технологического Института, ул. Голомб, д. 52, 5883754 Холон, Израиль.

E-mail: natalie4@zahav.net.il 


\section{DISCUSSION ON THE TYPES OF LITERARY TRANSLATION IN THE SOVIET TRANSLATION STUDIES}

This is an open access article distributed under the Creative Commons Attribution 4.0 International (CC BY 4.0)
(C) 20I7. N.R. Neiman

Holon Institute of Technology, Holon, Israel Received: March 27, 2017

Date of publication: June 25, 2017

Abstract: The article discusses the theory and history of literary translation in the Soviet Union, namely, the dispute between Moscow and St. Petersburg schools of translation. The main focus is on the chapter from an unfinished Doctorate thesis by a Soviet translator and translation studies theorist V.Ye. Shor (I9I7-I97I). The thesis entitled How Many Types of Translation Exist? was turned down by the editors of major academic collections in the field. Shor opposed ideas supported by the school of I. Kashkin though he did it indirectly, by criticizing Vachtin, a scholar who did not belong to the Moscow school of translation. Shor argued against dividing translation into types claiming that the type of translation should be determined by the original. Instead, he proposed a unified universal principle that would define the quality criteria of a translation, substantiate the necessity of translator's creativity, and at the same time adequately render ideas and images of the original in the language of translation. This paper shows how fierce discussions between the acolytes of these two schools influenced the decision to reject Shor's paper that fostered ideas not corresponding with the mainstream lines in translation studies of the i96o-s.

Keywords: literary translation, theory and history of translation in the USSR, translation types, word for word translation, loose translation, scientific translation, St. Petersburg school of translation

Information about the author: Nathalie R. Neiman, PhD, Lecturer in English at Holon Institute of Technology, 52, Golomb st., 5883754 Holon, Israel.

E-mail: natalie4@zahav.net.il 
Более семидесяти лет советской власти - уникальная эпоха в развитии теории и практики художественного перевода. Ни до, ни после не было такого расцвета переводческого искусства, не было такого количества талантливых переводчиков, воссоздававших литературу разных стран на русском языке. Для осуществления задачи познакомить массового читателя с произведениями писателей всего мира М. Горьким в г9г9 г. было создано издательство «Всемирная литература», и потребовались переводчики, способные в достаточно сжатые сроки квалифицированно перевести огромное количество литературы. Художественный перевод, бывший до этого в основном дилетантским занятием, превратился в уважаемую профессию. Именно в Петербурге в г919 г. Н. Гумилев, К. Чуковский и Ф. Батюшков сформулировали основные критерии художественного перевода [го]. В Петербурге же в г920-е гг. была создана первая в Советском Союзе секция переводчиков при ленинградском отделении Всероссийского союза писателей [6]. Она и заложила основы петербургской школы художественного перевода. Петербургская школа отличается от московской более академическим отношением к переводимому подлиннику, стремлением передать смысловое и эмоциональное содержание подлинника адекватными структурами в языке перевода. Недаром именно в Ленинграде (Петербурге) стала формироваться теория художественного перевода в работах К. Чуковского [I4], А.А. Смирнова, М.П. Алексеева [II]. К началу г940-х гг. оформилась теория А.В. Федорова - одного из первых специалистов в области теории художественного перевода [Із]. М.Л. Лозинский выразил свою приверженность научно-художественному подходу к переводу на Первом Всероссийском 
совещании переводчиков в 1936 г. [4]. В г953 г. вышел основополагающий труд А.В. Федорова «Введение в теорию перевода», дополненный и переработанный в І968 г. [г2]. В начале г960-х гг. оформилась «историко-литературная» теория Ю.Д. Левина [7] и Е.Г. Эткинда [І9], а также появились другие теории, включая теорию «полноценного художественного перевода» В.Е. Шора.

B.Е. Шор (I9I7-I97I) не успел закончить свою книгу-диссертацию «Чужое, но свое», но даже опубликованные фрагменты его работы, как прижизненные, так и посмертные, появившиеся в сборниках «Тетради переводчика» [18] и «Мастерство перевода» [15], а также в книге «Корифеи художественного перевода. Петербургская школа. В.Е. Шор и И.Я. Шафаренко» [I7], позволяют получить представление о его идеях, отличавшихся от положений авторов других теорий.

В.Е. Шор разрабатывал теорию перевода, основываясь на своем личном опыте переводчика I950-х - начала I960-х гг., на сравнении переводов других авторов и соотнесении их с текстом и литературным антуражем подлинника, он также использовал обширные знания о переводах и переводчиках, которые приобрел за время работы библиографом в каталоге переводных изданий Алисы Умикян, и в спорах с друзьями-коллегами Е.Г. Эткиндом и Ю.Д. Левиным.

Проспект книги Шора, составленный Е.Г. Эткиндом вместе со вдовой Шора И.Я. Шафаренко, включает две части - теоретическую (8 глав), которая посвящена собственно теории перевода, и практическую (5 глав), в которой анализируются основные этапы художественного перевода в советское время, а также проводится сравнительный анализ переводов произведений писателей XX в., работавших в разных жанрах (Л. Фейхтвангера, А. Франса, Р. Роллана и С. Цвейга).

Необходимость дальнейшей разработки теории перевода Шор обосновывает следующим образом: «Теория перевода поднялась от уровня практической технологии и методики и стала одной из литературоведческих наук, соприкасающейся через стилистику с языкознанием» [I6, c. Iоo].

В своих исследованиях Шор в основном полемизирует с И. Левым [8], Э. Кари [2І], Т. Сэйвори [23] и Ю. Найда [22], отталкиваясь от их идей для разъяснения своей позиции в этой области. Свои основные положения Шор разрабатывает, критикуя теории коллег-переводчиков, пользуется 
термином «полноценный перевод» как главной характеристикой качественного перевода. При этом он говорит «не об однозначных предписаниях, а о принципиальных путях решения аналогичных задач», выявляя «возможность множественности более или менее удачных решений одной и той же переводческой задачи» [I6, с. IоI]. Он занимается сравнительным изучением переводов одного и того же произведения, выполненных разными переводчиками с г920-х по г96о-е гг., и показывает, как развивалось мастерство художественного перевода в зависимости от времени его создания и от следования переводчиком той или иной теории перевода. Шор пишет: «Сравнительное изучение переводов позволяет явственно продемонстрировать, что в языковой ткани произведения реализуется нерасторжимое единство его идейного содержания и художественной формы» [І8, с. 8].

В последние годы жизни Шор написал несколько статей на материале готовившейся диссертации и разослал их в различные сборники, посвященные проблемам перевода. Одной из них была статья «Сколько существует типов полноценного перевода?». Она является частью второй главы диссертации «История и типология художественного перевода». Статья была написана после г968 г., поскольку последняя ссылка по времени относится к переизданию книги А.В. Федорова. Однако эта статья так и не была опубликована и была возвращена вдове Шора более чем через десять лет после написания без объяснения причин.

По прошествии почти 50 лет со времени подготовки статьи Шором стала яснее вырисовываться перспектива развития теории перевода в Советском Союзе [I; 20] и появилась возможность разобраться, что же побудило составителей сборников по теории перевода отказаться от публикации этой статьи и задержать выход в печать других фрагментов из его диссертации на долгие годы ${ }^{\mathrm{I}}$

В начале статьи Шор четко определяет задачу, которую собирается решить: «Существуют ли реально и закономерны ли различные типы переводов художественных произведений?»², т. е. имеет ли теория перевода право на классификацию своих объектов?

\footnotetext{
I Статья Шора «Из истории советского перевода» была опубликована в сборнике «Мастерство перевода» (М.: Сов. писатель, 1985. Сб. І3. С. 304-331), который вышел только в 1990 г.

2 Сколько существует типов полноценного перевода // ЦГАЛИ. СПб. Ф. г4І. Оп. 2. Д. 26 а. Л. г.
} 
Шор делает предположение, что такая классификация возможна: «Наука вообще любит классифицировать, главную задачу множества филологических (преимущественно лингвистических) работ составляет классификационное упорядочение тех или иных явлений. Теория перевода - тоже одна из филологических дисциплин. Так почему же и при ее разработке не применить те же методы, что и в других отраслях филологии? Все переводы различны между собой, два переводчика никогда не переведут совершенно тождественно один и тот же текст. Не проще ли будет разбираться в многообразии индивидуальных переводческих манер и решений конкретных задач, если все переводы будут сведены к нескольким типам?»3

Однако типология переводов, по мнению Шора, может усложнить оценку перевода. Он пишет: «Прежде всего мы должны будем точно описать эти возможные типы, чтобы знать, по каким признакам относить перевод к тому или иному из них. Сделать это, очевидно, будет нелегко, и можно предвидеть недоразумения, когда критик перевода будет колебаться, относя перевод не к тому типу, к какому его относит сам переводчик, или же не соглашаться с переводчиком в определении типа его перевода. Таким образом, прежде чем браться за оценку перевода, нужно будет долго договариваться об определении его типа. Кроме того, придется выработать различные критерии качества применительно к каждому типу и не путать их. Это будет особенно трудно, потому что едва ли смежные типы будут настолько расходиться между собой, что можно будет на практике безошибочно, даже при весьма наметанном критическом глазе, пользоваться различными критериями, расхождение между которыми будет, как говорят математики, “пренебрежительно мало”. Похоже, что вместо упрощения мы получим такие осложнения, в которых, того и гляди, завязнешь» 4 .

Шор начинает свои рассуждения с определения советской теории перевода, назвав ее «теорией полноценного перевода», хотя такое определение соответствует именно теории Шора, а не другим существовавшим тогда теориям (А.В. Федоров придерживается терминов «верный» или «адекватный» перевод, И. Кашкин ратует за «реалистический» перевод и т. д.). Он описывает эту теорию как всеобщую, тогда как она представляет част-

3 Сколько существует типов полноценного перевода // ЦГАЛИ. СПб. Ф. І4І. Оп. 2.

Д. 26 а. Л. г.

4 Там же. 
ную точку зрения. Он пишет: «Созданная трудами К.И. Чуковского, И.А. Кашкина, О. Кундзича, А.В. Федорова, Е.Г. Эткинда и других советских переводоведов теория полноценного перевода вырастала в борьбе, с одной стороны, с вольничаньем, а с другой - с буквализмом. Она синтезировала то положительное, что содержалось в обоих направлениях, которые она отвергла, и обосновала диалектическое понимание перевода, утвердила необходимость индивидуального переводческого творчества, но отнюдь не “суверенного”, диктуемого только субъективными импульсами, а управляемого задачей возможно более полного воспроизведения оригинала в его художественной целостности»5.

По Шору получается, что все упомянутые теоретики перевода вели борьбу за одни и те же идеи и ими преодолены разногласия 50-х гг. благодаря победе над «буквализмом и вольничаньем» [I]. Но действительность оказалась несколько иной. Конечно, после яростных битв г950-х гг., спровоцированных политической «оттепелью» и выглядевших как сведение счетов между различными группами переводчиков, к середине І960-х гг. баталии в борьбе за единственно верный метод перевода несколько поутихли, поскольку главные участники дискуссий покинули наш мир: в 1958 г. умер Е. Ланн, в г963 г. - И. Кашкин, а также ушли из жизни Б. Пастернак и С. Маршак. Появились новые теоретики перевода, следующее поколение переводчиков набирало силу. Споры теоретиков перевода в г96о-е гг. были перенесены на страницы сборников, таких как «Тетради переводчика» (1963-І982) и «Мастерство перевода» (1959-1985); в г966 г. был проведен Всесоюзный симпозиум по проблемам перевода, материалы которого были собраны в книге «Актуальные проблемы теории художественного перевода» [2]. Этот симпозиум был знаковым событием в развитии теории перевода в г96о-е гг., поскольку на нем было предоставлено слово почти всем сколько-нибудь заметным переводчикам и переводоведам. Плюрализм мнений, разные методы решения проблем перевода, дискуссии по важнейшим вопросам переводческого мастерства предоставили возможность дальнейшим исследователям найти в этом сборнике то, что соответствует или противоположно их воззрениям. Нет практически ни одной работы по истории перевода после г967 г., которая бы не цитировала этот

5 Сколько существует типов полноценного перевода // ЦГАЛИ. СПб. Ф. І4І. Оп. 2. Д. 26 а. Л. г. 
сборник. Сборник не представил никакой общей теории, противостояние между представителями так называемых лингвистической и литературной теорий перевода сохранилось. Если в Петербурге в основном следовали теории А.В. Федорова, то в Москве главным теоретиком перевода оставался И. Кашкин, его идеи развивал Г. Гачечиладзе.

В такой обстановке выдавать свои идеи за общую теорию было во всех смыслах рискованно, поскольку статья Шора была послана в один из московских сборников по теории перевода, где настороженно относились к идеям, не совпадавшим с генеральным направлением в переводоведении.

Кроме того, в статье, опубликованной в сборнике «Мастерство перевода» [15], Шор много внимания уделяет идее «реалистического перевода», с жаром доказывая, что не может быть перевода реалистического, точно так же как не существует переводов символистских, сюрреалистических или формалистских (тем самым выступая против московских теоретиков «реалистического» перевода). Он возражает против внесения этих литературоведческих критериев в переводческую науку, поскольку «перевод в данном случае зависит от оригинала и у переводчика нет никаких прав менять приверженность автора к какому-либо течению» [15, с. 282]. Критерии верности перевода оригиналу, по мнению Шора, определяются «применительно к разным жанрам и родам литературы, стилям литературных течений и отдельных писателей». Таким образом, он объясняет, что практика перевода и оригинальное творчество - это не одно и то же, поскольку «мера преобразований, осуществляемых на основе субъективного, индивидуально-творческого выбора переводчика задается самим характером переводимого произведения художественной литературы <...> Субъективный выбор варианта должен быть обоснован заданием, вытекающим из самой природы переводимого произведения - из его текста прежде всего, а также из тех внетекстовых структур, с которыми соотносится оригинальный текст и должен соотноситься перевод» [І7, с. 395]. К внетекстовым структурам Шор относит саму историческую действительность, в которой данное произведение возникло, литературную традицию этого периода и мировоззрение автора. Кроме того, «внетекстовыми структурами являются также идейно-эмоциональные особенности различных читательских групп и отдельных индивидуумов», под которыми Шор подразумевает также и переводчиков - они, «как ученые, способны подняться над своим 
субъективным восприятием произведений литературы и реконструировать первоначальное его восприятие», которое в другую эпоху не может быть тождественным восприятию его современниками» [I7, с. 389-390].

Создается впечатление, что Шор пытается примирить все враждующие стороны, соединяя разные точки зрения на перевод и подводя их под понятие «полноценного перевода». Он пытается взять самое ценное и от приверженцев буквализма, и от сторонников вольничанья, а также объединить литературоведческую теорию перевода с лингвистической через стилистику. Он пишет: «Истинная верность перевода оригиналу недостижима без творчества, то есть, иначе говоря, что верный перевод может быть создан только переводчиком-художником. Результаты переводческого творчества должны проверяться их общей художественной ценностью (трудная, но в известных пределах осуществимая эстетико-литературоведческая задача) и мерой их соответствия, на основе современных научных критериев, глубоко понятому, в смысловом, языковом и художественном отношениях, оригиналу (задача также нелегкая, но более определенная, разрешимая в значительном приближении благодаря уже наметившейся методологии подхода к ней). Иначе говоря, переводчик должен быть не только художником, но и ученым-филологом. Художник и ученый - две нераздельные ипостаси настоящего мастера художественного перевода» ${ }^{6}$.

Можно себе представить, что эта попытка примирения сторон не нашла союзников среди редакторов сборников по теории перевода в Москве.

Но Шор идет дальше. Он считает, что наука должна установить «единый универсальный принизи художественного перевода, приложимый ко всем родам и видам литературных произведений, не предусматривающий никаких исключений и спецификаций в зависимости от каких-либо особых задач»7. Безапелляционно, в духе советских исследователей, он заявляет, что «любой перевод, не удовлетворяющий этому принципу, не может считаться полноценным и потому не должен признаваться равноправным с теми переводами, которые ему удовлетворяют» ${ }^{8}$. По мнению Шора, «современная теория дает определенный, но и достаточно широкий критерий

6 Сколько существует типов полноценного перевода // ЦГАЛИ. СПб. Ф. г4г. Оп. 2. Д. 26 а. Л. І.

7 Сколько существует типов полноценного перевода // ЦГАЛИ. СПб. Ф. І4І. Оп. 2.

Д. 26 а. Л. 2.

8 Там же. 
полноценности перевода. Она видит свою задачу не в том, чтобы априорно регламентировать все требования к переводу, но чтобы научно обосновать необходимость творческих поисков, одновременно точно определив их цель. Она оставляет широкий простор для индивидуальных решений творческих задач, утверждая опять-таки как научную истину принципиальную невозможность однозначных решений, но притом очерчивает допустимые границы их разновариантности. Более того, она допускает парадоксальную ситуацию существования непохожих друг на друга переводов одного текста, но в равной мере верных оригиналу. Она оставляет место и для суждений вкуса, но суживает сферу их приложения, указывая на объективные критерии качества перевода, ограничивающие возможности предвзятой или недобросовестной его оценки. Сила этой теории - в слиянии эстетического и филологического подходов к переводу, которые, будучи верно понятыми, оказались в конечном итоге единым подходом. В переводческом деле самое могучее творческое вдохновение без филологического анализа оригинального текста, без уважения к этому тексту не приведет к действительному переводу, так же как самый тщательный анализ оригинала и преклонение перед ним без творческого полета не смогут дать произведению полнокровную жизнь на другом языке» .

(Вполне вероятно, что внутренние рецензенты статьи увидели в идеях Шора что-то похожее на теорию «идеального» перевода и не стали рисковать и публиковать его идеи, которые не находили поддержки у представителей московской школы перевода.)

После такого вступления Шор переходит к попыткам классифицировать якобы существующие и якобы равноправные виды подходов к переводу и, соответственно, распределить все переводы по нескольким типам.

Он вступает в полемику с выступившим на Всесоюзном симпозиуме по художественному переводу востоковедом-синологом и переводчиком Б.Б. Вахтиным [3], который делит переводы на три класса: І) научный, 2) художественный и 3) промежуточный. Шор выбирает Б. Вахтина своим главным противником, поскольку его точка зрения диаметрально противоположна теории Шора, и поэтому уязвимые положения теории Б. Вахтина было легко критиковать.

9 Сколько существует типов полноценного перевода // ЦГАЛИ. СПб. Ф. І4І. Оп. 2. Д. 26 а. Л. 2-3. 
По мнению Вахтина, научный перевод призван «сообщить читателю максимум достоверных сведений о поэтическом тексте, недоступном читателю из-за незнания языка, на котором написан переводимый текст» [3, c. 22]. При этом «переводчик должен избегать соблазна передать читателю непосредственно художественное целое, ибо малейшее увлечение, малейшее участие личности переводчика сразу же исказит объективную достоверность такого перевода» [3, с. 23].

Шор считает, что результатом переводческой работы «научного типа» «бывает, как правило, лишь полуфабрикат, обычно называемый подстрочником. Последний может быть и, к сожалению, до сих пор является в ряде случаев необходимым, но его, как правило, не печатают, и возводить его в ранг перевода не принято. Более того, подстрочник может быть составлен весьма тщательно, но он никогда не станет действительно научным переводом, потому что сумма различных элементов - отнюдь не то, что их органическое единство, и сами они, будучи вычленены из целого, могут изменить свой характер до неузнаваемости. Подстрочник можно дать в руки поэту, рассчитывая на синтезирующую силу его творческого воображения (хотя и в этом случае чрезвычайное искажение оригинала более чем вероятно), но ни читателю, ни ученому он не нужен. Первому он ничего не скажет о том, что представляет собой на самом деле оригинал, а второй, если он настоящий ученый, предпочтет выучить язык, на котором написан оригинал. Конечно, при переводе стихов стихами, да еще рифмованными, мера семантической точности неизбежно меньше, чем при прозаическом их переводе. Поэтому французы, с их рационалистической традицией, до самого последнего времени предпочитали прозаические переводы стихов. Но и они преодолевают ныне эту традицию, научной критики не выдерживающую. И впрямь - можно ли утверждать, что при переводе стихов во всех случаях главное - семантическая точность?» ${ }^{\text {1о }}$

Как доказательство своей правоты Шор приводит примеры из практики перевода. «В истории русского перевода переводы типа подстрочника, вынесенные на широкую публику и сыгравшие известную положительную информационную роль, можно перечислить по пальцам. Это - “Слово о полку Игореве” в переводе академика А.С. Орлова и в новом

Iо Сколько существует типов полноценного перевода // ЦГАЛИ. СПб. Ф. І4І. Оп. 2.

Д. 26 а. Л. 4-5. 
переводе А.А. Дмитриева, Д.С. Лихачева и О.В. Творогова, “Отелло” Шекспира в переводе М.М. Морозова - и что еще? Переводчики буквалистического направления Б. Ярхо (“Песнь о Роланде”), Г. Шенгели (Гюго, Байрон, Верхарн), В. Гиппиус (Гейне), Е. Ланн (Диккенс) действительно полагали, что их “точность” носит научный характер, но притом искренно верили, что создаваемые ими переводы являются вполне художественными. Они заблуждались и в том, и в другом. Их вербальная “точность” была формальной, поверхностной, и ценой ее была такая неточность во всех прочих отношениях, что их переводы являются научными не в большей степени, нежели художественными, а что касается художественности буквалистских переводов, то ей давно уже дана заслуженная оценка» ${ }^{\text {г }}$

Как считает Вахтин, художественный перевод по методу прямо противоположен научному. «Его задача - воссоздать впечатление, полученное переводчиком от оригинала. Это впечатление совершенно субъективно...» [3, с. 23]. Далее развивается концепция, суть которой состоит в том, что никакие объективные критерии качества художественного перевода невозможны, ибо «мы не знаем, какова объективная реальность, которую он (переводчик. - В.Ш.) переводит», и, «строго говоря, никакого объективного стихотворения “Я помню чудное мгновенье” нет, а есть лишь сумма субъективных восприятий» [3, с. 26].

Шор считает, что «едва ли нужно затрачивать усилия, чтобы доказывать несостоятельность попытки обосновать безудержный произвол в художественном переводе утверждением, будто переводимое художественное произведение не представляет собой объективной реальности. Утверждение это противоречит всей истории социального функционирования литературы, восприятия ее общественным сознанием. Из того несомненного факта, что восприятие художественного произведения модифицируется в зависимости от тезауруса читателя (а сам этот тезаурус имеет не только индивидуальные, но и социально-групповые и эпохальные характеристики), делается совершенно неправомерный и исторически недоказуемый вывод об отсутствии в произведении инвариантного объективного субстрата. Не задерживаясь далее на этом пункте, укажем на внутреннюю противоречивость предложенной концепции. Если уж такой объективной реальности,

II Сколько существует типов полноценного перевода // ЦГАЛИ. СПб. Ф. І4І. Оп. 2. Д. 26 а. Л. 5 . 
как стихотворение “Я помню чудное мгновенье”, вовсе не существует, то как можно гарантировать объективность информации, сообщаемой так называемым “научным” переводом? Если нам заявят, что не существует “только” стихотворения, но имеется некая сумма языковых явлений, подлежащих воспроизведению в научном переводе, то на это мы возразим, что и смысла отдельных языковых компонентов нам не удастся таким способом раскрыть, ибо они являются лишь строительным материалом некоей супраструктуры и приобретают свое подлинное значение только в свете своей функции в ней и в зависимости от их взаимоотношений в составе того самого целого, которого якобы не существует» ${ }^{12}$.

Шор принципиально не согласен с концепцией Вахтина, которая, по его мнению, «разводит науку и творчество по разным ведомствам, отдает “богу богово, а кесарю кесарево” главным образом ради того, чтобы утвердить право переводчика-художника на бесконтрольную свободу» ${ }^{\mathrm{3}}$. Концепция Вахтина противоречит одной из главных идей теории Шора, что переводчик в своем творчестве ограничен самим характером переводимого произведения художественной литературы.

Шор пишет: «Провозглашение бесконтрольной свободы равнозначно запрещению оценивать перевод с точки зрения его верности оригиналу. Таким образом, свобода для переводчика оборачивается стеснением критики. Какая уж тут верность, если и оригинала-то нет, а есть только "впечатление” от него? Вот только интересно знать, от чего именно проистекает впечатление? Если объективно существующего произведения, “строго говоря”, нет, то источник “впечатления” есть фикция, и оно возникает из ничего. Но если “что-то, производящее впечатление” все-таки есть, то что это такое, в конце концов? "Вещь в себе”, о которой решительно ничего сказать нельзя, кроме того, что она как-то воздействует на наши чувства?

Поскольку переводимому произведению отказывается в праве быть объективной реальностью, то нет оснований считать таковой и самый перевод. Его, надо полагать, тоже нет, а есть лишь сумма впечатлений от него (от чего?). Можно ли при таком подходе отличить хотя бы хороший, действительно художественный перевод от плохого, нехудожественного? Можно ли,

I2 Сколько существует типов полноценного перевода // ЦГАЛИ. СПб. Ф. І4І. Оп. 2.

Д. 26 а. Л. 3.

I3 Там же. 
наконец, отличить перевод от не-перевода? И не теряет ли при этом слово “перевод” уже и свой сущностный, смыслообразующий признак? “Строго говоря”, оказывается необязательным не только анализ оригинала, но даже и его внимательное прочтение. Кто вправе предписать это переводчику, если он “сам - свой высший суд” и ничем, решительно ничем не отличается от оригинального автора? Он может знакомиться с оригиналом на слух, по пересказу или вообще вообразить его себе на пустом месте. Выводы абсурдные, но прямо вытекающие из концепции, отрицающей объективность оригинала» ${ }^{4}$.

По мнению Шора, идея «“суверенности” переводчика имеет две стороны. С одной стороны, ущемляются права критика и читателя, суждения которых при сверке подлинника с переводом априорно объявляются субъективными. Об искажениях оригинала они и заикнуться не смеют, потому что самого такого понятия быть не может» ${ }^{15}$.

С другой стороны, свобода переводчика также ограничивается концепцией Вахтина. Б.Б. Вахтин пишет: «Если научный перевод должен быть свободен от претензий на художественность, то и художественный перевод должен быть свободен от претензий на научность, ибо его цель не сообщение точной информации, а сообщение неопределенного впечатления» [3, с. 2324]. Таким образом, получается, что автор концепции предъявляет нормативные требования к переводчику: «Теперь переводчику “научному” нужно будет во что бы то ни стало вытравлять художественность, а "художественному" - научность. А если он не добьется этого или не захочет добиваться? Выходит, тут у него нет свободы? Он тогда нарушит строго установленную типологию переводов, будет делать то, что делать не “должен”» ${ }^{16}$.

И здесь Вахтин предлагает еще один тип перевода - «промежуточный», представляющий собой «компромисс» между первыми двумя. Шор считает, что «допущение третьего типа есть непринципиальное отступление от концепции, фактическое признание того, что оба предыдущие типа если не фиктивны как переводы, то, во всяком случае, неудовлетворительны каждый по-своему. Но в каких случаях желателен такой промежуточный перевод, если переводчик должен как раз избегать промежуточности, оста-

I4 Сколько существует типов полноценного перевода // ЦГАЛИ. СПб. Ф. І4І. Оп. 2.

Д. 26 а. Л. 3-4.

I5 Там же. Л. 4.

I6 Там же. 
ется неясным. Вместо того чтобы быть признанным высшим типом перевода, “промежуточный” тип допускается как бы нехотя, как навязанный силой фактов, но эклектический и потому только терпимый» ${ }^{17}$.

Возвращаясь к реальной практике перевода, в противовес высказываниям Вахтина, Шор отстаивает мнение, что «крупнейшие русские и советские ученые-филологи, выступая в качестве переводчиков, стремились, как правило, к созданию полноценных художественных и притом научно обоснованных переводов. Перевод “Декамерона” Боккаччо, выполненный одним из основателей русской филологической науки А.Н. Веселовским, ныне превзойден переводом Н.М. Любимова, но это был безусловно художественный перевод. Выдающийся разносторонний филолог А.А. Смирнов создал превосходные переводы ирландских саг, произведений Лопе де Веги, Лафонтена, Мериме, Анри де Ренье, Мопассана, Роллана, был наставником и редактором многих ныне действующих талантливых переводчиков. “Назидательные новеллы” Сервантеса, “Манон Леско” аббата Прево в переводе крупнейшего знатока западноевропейских литератур Б.А. Кржевского полностью отвечают современным требованиям к художественному переводу и переиздаются в наши дни. Никакой специальной установки на “научность" в противовес художественности нет в хрестоматиях по литературам Средних веков, Возрождения и XVII века, составленных Р.О. Шором и Б.И. Пуришевым. В них наряду с выдающимися русскими поэтами (А. Блок, Н. Гумилев, Ю. Верховский) представлены своими работами поэты-переводчики (В. Левик, О. Румер, Е. Васильева) и ученые-литературоведы, выступающие также в качестве переводчиков (В. Дынник, Р. Шор и др.). Если некоторые из помеченных в этих книгах переводов недостаточно художественны, то не потому, что этому препятствовала какая-то специальная “научная” установка. Высокими художественными достоинствами отмечены переводы крупнейших советских ученых-ориенталистов - академиков В.М. Алексеева (новеллы Ляо Чжая - с китайского), И.Ю. Крачковского (“Калила и Димна”, Коран - с арабского) ${ }^{18}$, Е.Э. Бертельса (“Кабус-намэ”, “Гулистон”

\footnotetext{
I7 Там же.

I8 «Перевод «Калилы и Димны», упоминаемый в диссертации В.Е. Шора, выполнен

И.Ю. Крачковским и И.П. Кузьминым (М.; Л., І934). По утвердившемуся мнению,

«Коран» в переводе И.Ю. Крачковского отличается прежде всего не «художественными достоинствами», а «филологической точностью передачи арабского текста»: ученый «часто
} 
Саади - с фарси). Лишь в редких случаях ученые-переводчики заявляли, что их перевод, воссоздавая формальные особенности оригинала, не претендует на художественность. Такая оговорка содержится, например, в предисловии академика А.П. Баранникова к его переводу знаменитой индийской поэмы “Рамаяна” Тулси Даса. Если скромность, выказанная академиком А.П. Баранниковым, заслуживает похвалы, то о самом переводе этого сказать нельзя. Он настолько неудобочитаем, что читателю остается совершенно непонятно, почему “Рамаяна” признается неувядаемым поэтическим шедевром. Гигантский труд, затраченный на перевод этого огромного произведения (оно переведено к тому же с сохранением стихотворной формы и просодии оригинала), практически оказался неплодотворным. И опять же - можно ли объявлять “научным” перевод поэтического произведения, из которого искусственно вынута его художественная сущность?

Вот уже более I5 лет издательство Академии наук СССР (с 1963 г. именующееся “Наука”) выпускает серию “Литературные памятники”. В редакционную коллегию серии входили крупнейшие советские филологи, ныне покойные: академики В.В. Виноградов, В.М. Жирмунский, Н.И. Конрад. В ее составе поныне такие первоклассные ученые, как академики М.П. Алексеев, Д.С. Лихачев. Под маркой серии опубликованы многие замечательные произведения мировой литературы. Издания снабжены самым серьезным научным аппаратом. Переводы, появившиеся в этих изданиях, осуществлены на основе общих принципов советской переводческой школы. Научная добросовестность в них не приходит в противоречие с художественностью, напротив - одно предполагает другое. Эти переводы в принципе ничем не отличаются от тех, которые публикует издательство “Художественная литература”. В обоих издательствах выступают одни и те же переводчики, среди которых немало высокоталантливых мастеров. Они не меняют своей переводческой манеры по дороге от Ново-Басманной улицы к Подсосенскому переулку ${ }^{19} \gg^{20}$.

прибегал к подстрочной форме передачи арабского текста, иногда нарочито буквальной» (подробнее см. «Предисловие ко второму изданию» Корана (М., І986)». - Прим. ред. I9 На Ново-Басманной улице, д. І9 в Москве находилось издательство «Художественная литература», а в Подсосенском переулке, д. 2I - издательство «Наука».

20 Сколько существует типов полноценного перевода // ЦГАЛИ. СПб. Ф. І4І. Оп. 2. Д. 26 а. Л. 5-6. 
Все указанные факты позволили Шору прийти к выводу, что «рассуждения о существовании какого-то особого “научного” перевода в настоящее время по крайней мере являются беспредметными»².

Однако Шор отмечает, что в г950-е гг. существование двух типов перевода признавал И.А. Кашкин, хотя он, быть может, энергичнее, чем другие теоретики, обосновывал единый принцип перевода художественных произведений. Он полагал, что «в зависимости от того, к какому читателю адресуется переводчик, получает право на существование, наряду с высокохудожественным переводом, и перевод экспериментального типа, а с другой стороны, служебный или учебный перевод, вроде хорошего перевода прозой “Фауста” А. Соколовским или “Отелло” М. Морозовым» [5, c. I52]. Хотя И.А. Кашкин признавал за другими типами переводов, кроме «высокохудожественного», лишь второстепенное значение, они не получили «путевки в жизнь» и в таком качестве. Современная точка зрения на эту проблему, на наш взгляд, правильно сформулирована С.П. Маркишем, который пишет: «Существовало (а может быть, и сейчас существует) мнение, будто перевод выполняет две функции - познавательную и эстетическую и будто эти функции можно изолировать одну от другой. Вероятно, такая точка зрения лежит в основе “ученых" переводов, где точно каждое слово, но безнадежно, до неузнаваемости, искажено целое <...> Может быть, этот вид буквализма следовало бы назвать академизмом в переводе. Но как его ни называть, главное - это избавиться от него» [9].

Шор соглашается с мнением Маркиша и добавляет только, что, по его мнению, «никакой особой “академической” или “научной” разновидности перевода не существует» ${ }^{22}$, тем самым отказывая концепции Вахтина в праве на существование.

Отвечая на вопрос, вынесенный в заголовок, Шор пишет в заключение, что, отметая промежуточный тип перевода как неудовлетворительный, «концепция двух различных функций перевода научно несостоятельна и опровергнута жизнью. Подмена единого принципа, способного обеспечить полноценность перевода двумя или тремя принципами, означает не только отказ от главного достижения современной теории и практики перевода, но и сведение бесконечного многообразия индиви-

2I Там же. Л. 6.

22 Там же. 
дуальных творческих манер, для которых в пределах единого принципа открывается широкий простор, к нескольким сковывающим их “типам”. Эта типизация - от лукавого, и ее надо раз и навсегда отвергнуть, чтобы “не вводить в соблазн малых сих” ${ }^{23}$.

Отказавшись от деления переводов по типам, Шор выдвигает на первый план критерии качества перевода, позволяющие оценивать качество и мастерство переводчика, которые подробно разбираются в третьей главе его диссертации. Но эти идеи не увидели света, так же как и полемика с Вахтиным. В советское время существовала такая практика неодобрения идей - их замалчивание, когда статьи просто не публиковались и все делали вид, что их не существует. Почти такую же судьбу постигла и часть диссертации Шора, посвященной истории перевода І920-х гг., поскольку в ней был предпринят анализ переводческой деятельности О. Мандельштама и разбирался перевод романа «Кола Брюньон», выполненный В. Набоковым под псевдонимом В. Сирин. Даже наличие псевдонима без упоминания настоящего имени автора было препятствием к опубликованию статьи, которая увидела свет только в г990 г., когда были сняты все ограничения на упоминания этих прежде опальных писателей. Заявка на книгу Шора «Чужое и свое», поданная в г973 г. его вдовой при поддержке Е.Г. Эткинда, М.П. Алексеева и Е. Калашниковой, осталась без ответа в архивах издательства «Художественная литература», еще раз свидетельствуя о нежелании властей представить точку зрения на теорию и практику перевода, отличающуюся от уже существовавших.

Изучение истории художественного перевода в г96о-е гг. прошлого века только начинается, и можно ожидать, что последуют и другие работы, посвященные этому периоду истории перевода в Советском Союзе. 


\section{Список литературы}

Азов А. Поверженные буквалисты: Из истории художественного перевода в СССР в 1920-г96о-е годы. М.: Издат. дом Высшей школы экономики, 2013. 304 с. Актуальные проблемы теории художественного перевода // Материалы Всесоюзного симпозиума (25 февраля - 2 марта І966 г.). М., І967. Т. І. 353 с. / Т. 2. 34I с. Вахтин Б.Б. Выступление на Всесоюзном симпозиуме по художественному переводу // Актуальные проблемы теории художественного перевода. М., I967. Т. 2. С. $22-26$.

Земскова E.E. Стратегия лояльности. Дискуссия о точности художественного перевода на I-м всесоюзном совещании переводчиков г936 г. // Новый филологический вестник. 2015. № 4 (35). С. 74-75.

Кашкин И.А. Текущие дела // Мастерство перевода. Сб. ст. М.: Сов. писатель, I959. С. IO6-I52.

Кукушкина Т.А. К истории секции ленинградских переводчиков (1924-I932) // Институты культуры Ленинграда на переломе от І920-х к I930-м годам: Материалы проекта. URL: http://www.pushkinskijdom.ru/Default.aspx?tabid=I046o (дата обращения: 20.03.20I7).

Левин Ю.Д. Об исторической эволюции принципов перевода // Международные связи русской литературы. М.; Л.: Наука, І963. С. 5-63.

Левый Иржи. Творческое воспроизведение // Мастерство перевода. Сб. ст. М., I968. С. 440-469.

Маркиш С.П. Несколько заметок о переводе с древних языков // Мастерство перевода. Сб. ст. М., І959. С. I54-155.

Принципы художественного перевода. Статьи Ф. Батюшкова, К. Чуковского, Н. Гумилева. Петроград: Гос. изд-во, г920. 60 с.

Смирнов А.А., Алексеев М.П. Перевод // Литературная Энциклопедия: в II т. М.: Сов. энциклопедия, І934. Т. 8. С. 527.

Федоров А.В. Основы общей теории перевода. М.: Высшая школа, І968. 396 с. Федоров А.В. О художественном переводе. Л.: Гослитиздат, І94I. 260 с. Чуковский К.И., Федоров А.В. Искусство перевода. Л.: Асаdemia, I930. 235 с. Шор В.Е. Как писать историю перевода // Мастерство перевода. Сб. ст. М., І973. C. $28 \mathrm{I}-290$.

Шор В.Е. Об общем и своеобразном в переводах // Актуальные проблемы теории художественного перевода. М., І967. Т. І. С. 99-Іог.

Шор Владимир, Шафаренко Инна. Избранные переводы: поэзия, драматургия, проза / вступ. статья и коммент. Н.Р. Нейман. СПб.: Петрополис, 20I5. 474 с.

Шор В.Е. О завоеваниях советской переводческой школы (На материале переводов прозы Анатоля Франса) // Тетради переводчика. Ученые записки № 8. М.: Международные отношения, I97І. С. 37-54. Эткинд Е.Г. Поэзия и перевод. М.; Л.: Сов. писатель, І963. 430 с. 
20 Яснов М.Д. Хранитель чужого наследства // Иностранная литература. 20Iо. № I2. C. 22I-24I.

2I Cary E. L'indispensable débat // Proceedings of the $3^{\text {rd }}$ Congress of the International Federation of Translators. Bad-Godesberg, 1959. N.Y.: Pergamon Press, I963.

P. 2I-49.

22 Nida E.A. Toward a science of translating with special reference to principles and procedures involved in Bible translating. Leiden, I964. 33I p.

23 Savory Th. The art of translation. London: Jonathan Cape, I957. I59 p. 


\section{References}

Azov A. Poverzhennye bukvalisty: Iz istorii khudozhestvennogo perevoda $v$ SSSR v I920-I960-e gody [Defeated literalists: from the history of literary translation in the USSR in I929-I960s]. Moscow, Izdatel'skii dom Vysshei shkoly ekonomiki Publ., 2013. 304 p. (In Russ.)

Aktual'nye problemy teorii khudozhestvennogo perevoda [Relevant issues of the theory of literary translation]. Materialy Vsesoiuznogo simpoziuma (25 fevralia 2 marta I966 g.) [Proceedings of the All-Soviet Symposium, Feb. 25 - March 2, I966]. Moscow, I967. Vol. I. 353 p. Vol. 2. 34I p. (In Russ.)

Vakhtin B.B. Vystuplenie na Vsesoiuznom simpoziume po khudozhestvennomu perevodu [Presentation at the All-Soviet Symposium on literary translation]. Aktual'nye problemy teorii khudozhestvennogo perevoda [Relevant issues of the theory of literary translation]. Moscow, I967, vol. 2, pp. 22-26. (In Russ.)

Zemskova E.E. Strategiia loial'nosti. Diskussiia o tochnosti khudozhestvennogo perevoda na I-m vsesoiuznom soveshchanii perevodchikov $1936 \mathrm{~g}$. [Strategy of loyalty. Discussion on the subtleties of literary translation at the Ist All-Soviet Symposium of translators (I936)]. Novyi filologicheskii vestnik, 20I5, no 4 (35), pp. 74-75. (In Russ.) Kashkin I.A. Tekushchie dela [Current affairs]. Masterstvo perevoda. Sbornik statei [Art of translation. Collection of essays]. Moscow, Sovetskii pisatel' Publ., I959, pp. I06-I52. (In Russ.)

6 Kukushkina T.A. K istorii sektsii leningradskikh perevodchikov (I924-I932) [On the history of a circle of the Leningrad translators]. Instituty kul'tury Leningrada na perelome ot I920-kh k I930-m godam: Materialy proekta [Leningrad institutes of culture at the turn of the I920s and I930s]. Available at: http://www. pushkinskijdom.ru/Default.aspx?tabid=I0460 (Accessed 20 March 20I7). (In Russ.) Levin Iu.D. Ob istoricheskoi evoliutsii printsipov perevoda [On historical evolution of translation principles]. Mezhdunarodnye sviazi russkoi literatury [International ties of Russian literature]. Moscow, Leningrad, Nauka Publ., I963, pp. 5-63. (In Russ.)

8 Levyi Irzhi. Tvorcheskoe vosproizvedenie [Artistic reproduction]. Masterstvo perevoda. Sbornik statei [Art of translation. Collection of essays]. Moscow, I968, pp. 440-469. (In Russ.)

9 Markish S.P. Neskol'ko zametok o perevode s drevnikh iazykov [Notes on translation from ancient languages]. Masterstvo perevoda. Sbornik statei [Art of translation. Collection of essays]. Moscow, I959, pp. I54-I55. (In Russ.) Printsipy khudozhestvennogo perevoda. Stat'i F. Batiushkova, K. Chukovskogo, N. Gumileva [Principles of literary translation. Articles by F. Batiushkov, K. Chukovsky, and N. Gumilev]. Petrograd, Gos. izdatel'stvo Publ., I920. 60 p. (In Russ.) Smirnov A.A., Alekseev M.P. Perevod [Translation]. Literaturnaia Entsiklopediia: $v$ II $t$. [Literary Encyclopedia: in II vol.]. Moscow, Sovetskaia entsiklopediia Publ., I934, vol. 8, p. 527. (In Russ.) 
I2

Fedorov A.V. Osnovy obshchei teorii perevoda [The basics of the general theory of translation]. Moscow, Vysshaia shkola Publ., I968. 396 p. (In Russ.)

3 Fedorov A.V. O khudozhestvennom perevode [On artistic translation]. Leningrad, Goslitizdat Publ., I94I. 260 p. (In Russ.)

Chukovskii K.I., Fedorov A.V. Iskusstvo perevoda [Art of translation]. Leningrad, Academia Publ., I930. 235 p. (In Russ.)

Shor V.E. Kak pisat' istoriiu perevoda [How to write the history of translation]. Masterstvo perevoda. Sbornik statei [Art of translation. Collection of essays]. Moscow, I973, pp. 28I-290. (In Russ.)

Shor V.E. Ob obshchem i svoeobraznom v perevodakh [On the general and the specific in translation]. Aktual'nye problemy teorii khudozhestvennogo perevoda [Relevant issues of the theory of literary translation]. Moscow, I967, vol. I, pp. 99-IOI. (In Russ.)

Shor V. E., Shafarenko I. Izbrannye perevody: poeziia, dramaturgiia, proza [Selected translations: poetry, drama, and fiction]. Intro. and comment. by N.R. Neiman.

St. Petersburg, Petropolis Publ., 20I5. 474 p. (In Russ.)

Shor V.E. O zavoevaniiakh sovetskoi perevodcheskoi shkoly. (Na materiale perevodov prozy Anatolia Fransa) [On the achievements of the Soviet school of translation. On the translations from Anatole France]. Tetradi perevodchika [Translator's journals]. Uchenye zapiski № 8. Moscow, Mezhdunarodnye otnosheniia Publ., I971, pp. 37-54. (In Russ.)

Etkind E.G. Poeziia i perevod [Poetry and translation]. Moscow, Leningrad, Sov. pisatel' Publ., I963. 430 p. (In Russ.)

Iasnov M.D. Khranitel' chuzhogo nasledstva [Keeper of alien legacy]. Inostrannaya literatura, 20IO, no I2, pp. 22I-24I. (In Russ.)

2I Cary E. L'indispensable débat. Proceedings of the 3rd Congress of the International Federation of Translators. Bad-Godesberg, 1959. N.Y., Pergamon Press, I963, pp. 2I-49. (In French)

22 Nida E.A. Toward a science of translating with special reference to principles and procedures involved in Bible translating. Leiden, I964. 33I p. (In English)

Savory Th. The art of translation. London, Jonathan Cape, I957. I59 p. (In English) 